\title{
Reuse of water from biofloc technology for intensive culture of Nile tilapia (Oreochromis niloticus): effects on productive performance, organosomatic indices and body composition
}

\author{
Alfredo Gallardo-Collí (i) · Carlos Iván Pérez-Rostro (1) - Martha Patricia Hernández-Vergara $(\mathbb{D}$
}

Received: 6 November 2018/ Accepted: 15 February 2019/Published online: 22 February 2019

(C) The Author(s) 2019

\begin{abstract}
During a growout period of 14 weeks, the productive performance, organosomatic indices and body composition of the Nile tilapia Oreochromis niloticus cultivated at high density reusing the water from systems with biofloc technology (BFT) were evaluated. Two treatments: tilapia cultured in biofloc (TB) and tilapia cultured in reused water biofloc (RW) were established. Mixed sex, juvenile Nile tilapia (average weight and length: $79.28 \pm 14.44 \mathrm{~g}$ and $12.44 \pm 0.70 \mathrm{~cm})$ were stocked into 6 experimental units $\left(0.2 \mathrm{~m}^{3}\right)$ at a density of $100 \mathrm{fish} / \mathrm{m}^{3}$. Temperature, dissolved oxygen, total dissolved salts, $\mathrm{pH}, \mathrm{NH}_{4}-\mathrm{N}, \mathrm{NH}_{3}-\mathrm{N}$ and $\mathrm{NO}_{3}-$ $\mathrm{N}$ were recorded daily, while $\mathrm{NO}_{2}-\mathrm{N}$, general hardness, carbonate hardness and settleable solids were recorded weekly. The weight and length of the tilapias were recorded biweekly. Survival, productive performance, proximal composition and organosomatic indices of Nile tilapia were evaluated. The water parameters in $\mathrm{RW}$ treatment such as $\mathrm{pH}$, total dissolved salts, $\mathrm{NO}_{2}-\mathrm{N}, \mathrm{NO}_{3}-\mathrm{N}$ and carbonate hardness were significantly greater $(p<0.05)$, when compared to those obtained in TB treatment. Survival rate was $>98 \%$ under both treatments. The final weight $(\mathrm{TB}=163.09 \pm 42.34 \mathrm{~g}, \mathrm{RW}=159.23 \pm 39.92 \mathrm{~g})$, protein $(19.1 \%)$ and lipid $(2.2 \%)$ content of the tilapia were non-significantly different between treatments. In addition, no significant differences in the gonadosomatic and hepatosomatic indices were observed either between tilapia sex or between the treatments. The results suggest that the intensive cultivation of Nile tilapia in biofloc can be established using reuse water from BFT systems, without adverse effects on their survival, productive performance, proximal composition and gonadal development.
\end{abstract}

Keywords Aquaculture production - Flesh quality - Freshwater consumption - Gonadal development · Limited/zero-exchange systems $\cdot$ Physiological factors

\section{Introduction}

The freshwater dispute between different productive sectors, such as agriculture and energy, limits the availability and quality of water destined for continental aquaculture development (FAO 2018). Since the world's production of edible fish relies increasingly on continental aquaculture, which takes place in a freshwater environment, it is necessary to prolong the useful life of freshwater to guarantee aquaculture production (FAO 2018). To prolong the useful life of freshwater, it is necessary to use cultivation techniques that have an advantage over traditional fish farming practices; for example, using biofloc technology (BFT)

A. Gallardo-Collí · C. I. Pérez-Rostro $(\bowtie) \cdot$ M. P. Hernández-Vergara

Laboratorio de Mejoramiento Genético y Producción Acuícola, Instituto Tecnológico de Boca del Río, Km 12 Carretera

Veracruz-Córdoba, C.P. 94290 Boca del Río, Veracruz, Mexico

e-mail: ivandna02@hotmail.com 
(Avnimelech 2009). BFT is considered as the new blue revolution, because it exploits the proliferation of microorganisms (bacteria, fungi, microalgae and zooplankton) to maintain water quality, excluding pathogens and providing better nutrition to cultured organisms, which increases the production (Emerenciano et al. 2017). Additionally, it has been demonstrated that BFT has a positive effect on the proximal composition of the cultured organisms (Pérez-Fuentes et al. 2018), and the nutrition of broodstock (Ekasari et al. 2013), due to the consumption of the microorganisms present in the biofloc.

An additional benefit of BFT is the lower water consumption due to zero or minimum water exchange during production (Avnimelech 2009); for example, the freshwater consumption during the culture of prawn Macrobrachium rosenbergii, and Nile tilapia Oreochromis niloticus in BFT have been reported to be 6.8 and $0.071 \mathrm{~m}^{3}$ of water, respectively, per kilogram of production (Pérez-Fuentes et al. 2013, 2016). Similarly, a decrease in water consumption has been reported during the cultivation of shrimp Litopenaeus vannamei in salt water using BFT $\left(0.098-0.169 \mathrm{~m}^{3}\right.$ of water per kilogram of production) (Krummenauer et al. 2014). In contrast, traditional freshwater aquaculture uses an average of $16.9 \mathrm{~m}^{3}$ of water per kilogram of production; therefore, farming techniques that both intensify production and make use of natural resources, such as BFT, should be adopted (Verdegem and Bosma 2009).

The reduction in water consumption using BFT could be greater if the same water is reused in multiple culture cycles (Krummenauer et al. 2014). However, it is important to evaluate the impact that reuse water could have on the productive performance and nutritional quality of the cultivated organisms because the reuse of water from previous cultures could spread diseases or parasites to the new batch of fish or increase the accumulation of salts or toxic substances in the water (Boyd 2003) which, in turn, could potentially affect the production and quality of the final product. In addition, to evaluate productive performance and proximal composition of cultured organisms, the evaluation of organosomatic indices, that is, the ratios of organs to body weight, can provide important information about the health condition of the cultivated organisms since it is possible to establish a direct connection between environmental factors and their effect on the target organ, for instance, when a reduction or increase in size of key organs, such as liver or gonad, occurs (Dekić et al. 2016).

There is currently a scarcity of information in the literature regarding the cultivation of fish and crustaceans using biofloc and water that has been reused following other BFT cultures. In addition, most research has focused on the productive performance of the species without considering the effect on the body composition or the health status of the cultivated organisms. However, in a related study, Krummenauer et al. (2014) evaluated the cultivation of white shrimp L. vannamei using different proportions (ranging from 25 to $100 \%$ ) of reuse water, and observed that survival, growth and feed conversion rate of the shrimp were higher compared to values of the same parameters recorded from shrimp cultured in clear water. In contrast, Malpartida et al. (2017) established a biofloc culture of Nile tilapia, O. niloticus, using 50\% biofloc-rich water as inoculum, and did not observe adverse effects on the survival and productive performance of the tilapia caused by the water source.

Based on current knowledge, we hypothesize that Nile tilapia can be cultured in biofloc using up to $100 \%$ reuse water derived from other BFT systems because previous studies have shown that Nile tilapia tolerates adverse environmental conditions and is considered to be one of the most physiologically adaptable species to biofloc culture, which allows cultivation at high densities (Day et al. 2016; Pérez-Fuentes et al. 2016). If implemented successfully, this strategy could offer a sustainable alternative to both Nile tilapia production and water use. The objective of the study was to evaluate the productive performance, organosomatic indices and proximal composition of the Nile tilapia, $O$. niloticus, cultivated at a high density using water reused from prior BFT cultures.

\section{Materials and methods}

The study was carried out in the Laboratory of Genetic Improvement and Aquaculture Production of the Technological Institute of Boca del Rio, Veracruz, Mexico, over a 14-week grow-out period. 
Experimental design and system

A completely randomized design was used with two treatment conditions: tilapia culture in biofloc (TB) and tilapia cultured in biofloc utilizing reused water $(\mathrm{RW})$, with three replicates per treatment. Two fiberglass round tanks $\left(3.80 \mathrm{~m}^{2}\right.$ in area $\times 0.80 \mathrm{~m}$ deep water) were used for biofloc production (BP). A tank was filled with water from the artesian well and the other tank was filled with the supernatant water from a semiintensive tilapia BFT culture, which was previously sedimented for $96 \mathrm{~h}$. The water from both tanks was inoculated with $0.15 \mathrm{ml} / \mathrm{L}$ of chelated liquid fertilizer (Bayfolan Forte, Bayer Crop Science Division, Bayer, Mexico; composition $\% \mathrm{w} / \mathrm{w}=$ Total $\mathrm{N} 11.47 \%$, potassium as $\mathrm{K}_{2} \mathrm{O} 6.00 \%, \mathrm{~B} 0.036 \%, \mathrm{Cu} 0.040 \%, \mathrm{Fe}$ $0.050 \%$, Mo $0.005 \%$, Zn $0.080 \%$, thiamine hydrochloride $0.004 \%$, phosphorus as $\mathrm{P}_{2} \mathrm{O}_{5} 8.00 \%$, S $0.23 \%$, calcium as $\mathrm{CaO} 0.025 \%$, $\mathrm{Co} 0.002 \%$, $\mathrm{Mn} 0.036 \%$, magnesium as $\mathrm{MgO} 0.025 \%$, indoleacetic acid $0.003 \%$ ) to stimulate primary productivity and zooplankton growth (Pérez-Fuentes et al. 2016). The maturation period of the water in the tanks was 10 weeks. During this period, the water was aerated with two diffuser stones $(23 \mathrm{~cm} \times 2.5 \mathrm{~cm} \times 2.5 \mathrm{~cm}$ ) connected to a 1-HP (Sweetwater, Apopka, FL, USA) aerator. One week before the end of the biofloc maturation period, $150 \mathrm{~g}$ of molasses per day was added to promote the growth of heterotrophic bacteria.

At the end of the maturation period, three experimental tanks $\left(0.26 \mathrm{~m}^{2}\right.$ in area $\times 0.80 \mathrm{~m}$ deep water $)$ were annexed to each BP tank. In addition, one settling chamber per BP tank $\left(0.26 \mathrm{~m}^{2}\right.$ in area $\times 0.9 \mathrm{~m}$ deep water $)$ was used. All components were installed inside a greenhouse $(30 \mathrm{~m} \times 10 \mathrm{~m} \times 4.5 \mathrm{~m})$ covered with shade mesh (10\% brightness). During the study, floc-rich water was continuously recirculated, running from the BP tank into the experimental tanks by means of a submersible pump $(40 \mathrm{~L} / \mathrm{min})$ and was returned by gravity, the water lost by evaporation or sludge extraction was recovered with water from the artesian well (Fig. 1).

Nile tilapia culture

For the study, the BP and the experimental tanks were stocked with juvenile Nile tilapia $O$. niloticus (79.28 $\pm 14.44 \mathrm{~g}$ initial average weight and $12.44 \pm 0.70 \mathrm{~cm}$ initial average length) without sexual selection and maintained at a density of $100 \mathrm{fish} / \mathrm{m}^{3}$. The female:male ratio of the fish batch was 39:61 and 40:60 for TB and RW, respectively. A formulated feed (El Pedregal Silver Cup, Toluca, Mexico) composed of 32\% protein, 5\% lipids, 5\% fiber, 5\% ash and 12\% moisture (according to the manufacturer's warranty) was supplied to the tilapia twice daily (09:30 and 15:30 h). During the test, the feed was supplied equivalent to $2 \%$ of the total biomass was used. The amount of feed supplied to tilapia in the BP and experimental tanks was adjusted after each biometry. For biometric data, 40 fish from the BP tank and 20 fish per experimental tank were measured (weight and standard length) biweekly.

During the grow-out period, a constant C:N ratio of 12.5:1 was achieved in the biofloc using molasses as a carbon source (40\% C determined by elemental analysis). The amount of carbon (molasses) used per treatment was determined in relation to the feed ration and its protein content; the molasses was divided into two fractions and were added every 5 days to avoid an abrupt reduction in the concentration of dissolved oxygen in the water (Pérez-Fuentes et al. 2016).

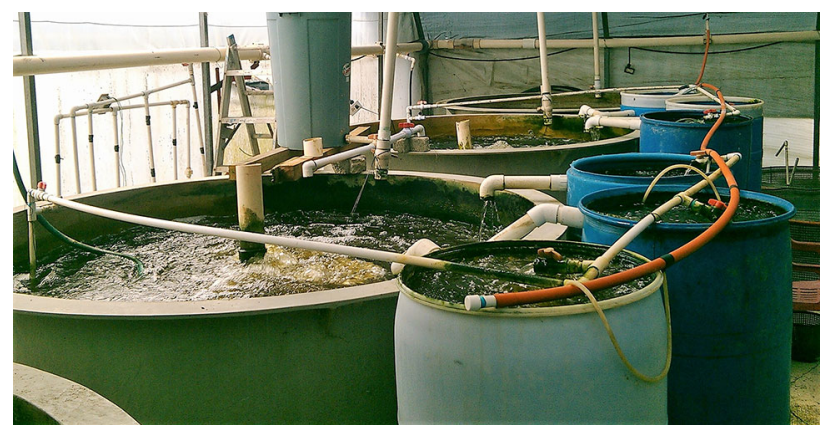

Fig. 1 The tank and experimental units used during Nile tilapia Oreochromis niloticus culture in biofloc with reused water 
Productive performance and gonadosomatic indices of Nile tilapia

Productive performance of Nile tilapia was evaluated according the following indices (Pérez-Fuentes et al. 2018):

Survival $(\mathrm{S}, \%)=($ number of live fish/number of fish stocked $) \times 100$

Daily weight gain $(\mathrm{DWG}, \mathrm{g} /$ day $)=\left[\right.$ final live weight $\left(W_{\mathrm{f}}, \mathrm{g}\right)-$ initial live weight $\left.\left(W_{\mathrm{i}}, \mathrm{g}\right)\right] /$ Time $(t$, days $)$

Specific growth ratio $(\mathrm{SGR}, \% /$ day $)=\left[\left(\ln W_{\mathrm{f}}-\ln W_{\mathrm{i}}\right) / t\right] \times 100$

Condition factor $(\mathrm{K})=\left[(\right.$ body weight, $\mathrm{g}) /$ length $\left.^{3}\right] \times 100$; length being in $\mathrm{cm}$

Feed conversion ratio $(\mathrm{FCR})=$ feed consumed $(\mathrm{g}) /$ fish weight gain $(\mathrm{g})$

Coefficient of variation $(\mathrm{CV}, \%)=($ standard deviation $/$ mean $) \times 100$

Total production $\left(\mathrm{TP}, \mathrm{Kg} / \mathrm{m}^{3}\right)=[(\mathrm{S} \times$ number of fish stocked $\times$ mean final weight $(\mathrm{FW}, \mathrm{kg})] /$

water volume $\left(3.6 \mathrm{~m}^{3}\right)$

At the end of the study, 10 fish from each experimental tank were anaesthetized in clove oil solution $(75 \mathrm{mg} /$ L). Subsequently, the fish were weighed and measured, killed by a cranial puncture and, under aseptic conditions, the fillet, gonads, and liver were extracted. The tilapia fillet was obtained by cutting the muscle mass on each side of the fish, from the dorsal muscle to the ventral muscle, omitting spines and skin. The fillet yield and the organosomatic indices were evaluated according to the following indices (Oliveira et al. 2014; Pérez-Fuentes et al. 2016):

$$
\begin{aligned}
& \text { Fillet yield }(\%)=[\text { fillet weigth }(\mathrm{g}) / \text { body weight }(\mathrm{g})] \times 100 \\
& \text { Gonadosomatic index }(\text { GSI, } \%)=[\text { gonad weight }(\mathrm{g}) / \text { body weight }(\mathrm{g})] \times 100 \\
& \text { Hepatosomatic index }(\text { HSI, } \%)=[\text { liver weight }(\mathrm{g}) / \text { body weight }(\mathrm{g})] \times 100
\end{aligned}
$$

Proximal composition of Nile tilapia and biofloc

To determine the proximal composition of the tilapia, the fillets obtained from the fish of each experimental tank were homogenized. A sample of the resulting mixture was taken, which was crushed in a mortar to obtain a paste, then packed into plastic bags and stored at $-5^{\circ} \mathrm{C}$ until analysis. The moisture content of the fillets was determined using a convection oven (Memmert UNP 400, Schwabach, DEU) heated to $135{ }^{\circ} \mathrm{C}$ for $2 \mathrm{~h}$. The crude protein was determined with an elemental analyzer (Flash 2000, Term Fisher Scientific, Waltham, Massachusetts, USA) $(\mathrm{N} \times 6.25)$; total lipids were extracted by soxhlet method using the methanol-chloroform solvent in a 2:1 ratio; ash was calculated after sample incineration at $600{ }^{\circ} \mathrm{C}$ for $2 \mathrm{~h}$ in a furnace muffler (Felisa, Jalisco, Mexico), each measurement was taken in triplicate, in accordance with AOAC (1990).

During the fourth, eighth and fourteenth week of the grow-out period, a sample of biofloc (80-100 g wet weight) was taken to determine its proximal composition. The biofloc sample was obtained from the BP tank after filtering approximately $200 \mathrm{~L}$ of water through a $50-\mu \mathrm{m}$ mesh. The moisture in the biofloc was estimated by dehydration at $60{ }^{\circ} \mathrm{C}$ for $24 \mathrm{~h}$. The dehydrated biofloc samples were pulverized and stored at $-5{ }^{\circ} \mathrm{C}$ until their analysis. The crude protein, total lipids and ash contents were estimated with the methodology and instrumentation previously indicated for the fillet samples. The conversion factor of $\mathrm{N} \times 5.9$ was used to calculate the protein content from nitrogen (Liu et al. 2016). All measurements were performed in triplicate.

Physicochemical parameters of water

Physicochemical parameters of water were recorded daily at $10 \mathrm{~h}$. Temperature $\left(T,{ }^{\circ} \mathrm{C}\right)$, dissolved oxygen (DO, $\mathrm{mg} / \mathrm{L}$ ), total dissolved salts (TDS, $\mathrm{mg} / \mathrm{L}$ ), ionized ammonia $\left(\mathrm{NH}_{4}-\mathrm{N}, \mathrm{mg} / \mathrm{L}\right.$ ), non-ionized ammonia $\left(\mathrm{NH}_{3}-\mathrm{N}, \mathrm{mg} / \mathrm{L}\right)$ and nitrate $\left(\mathrm{NO}_{3}-\mathrm{N}, \mathrm{mg} / \mathrm{L}\right)$ were measured with a multi-sensor (Professional Plus model, YSI, Yellow Springs, OH, USA), and $\mathrm{pH}$ was measured using EcoTestr ${ }^{\mathrm{TM}} \mathrm{pH} 2$ (Pérez-Fuentes et al. 2018). The concentration of nitrite $\left(\mathrm{NO}_{2}-\mathrm{N}, \mathrm{mg} / \mathrm{L}\right)$, general hardness $(\mathrm{GH}, \mathrm{mg} / \mathrm{L})$ and carbonate hardness $(\mathrm{KH}, \mathrm{mg} / \mathrm{L})$ 
were determined by colorimetry (Hagen Nutrafin, Mansfield MA) and settleable solids (SS, $\mathrm{ml} / \mathrm{L}$ ) with $1000 \mathrm{~mL}$ Imhoff cones after 20 min of sedimentation (Pérez-Fuentes et al. 2018). When the SS concentration was $>50 \mathrm{~mL} / \mathrm{L}$, the biofloc was partially removed from the water using the settling chamber. Calcium hydroxide was used to increase the carbonate hardness $\left(\geq 100 \mathrm{mg} / \mathrm{L}\right.$ of $\left.\mathrm{CaCO}_{3}\right)$ and $\mathrm{pH}(\geq 7.0)$ of water when these parameters decreased to $\mathrm{KH}<80 \mathrm{mg} / \mathrm{L}$ and $\mathrm{pH}<6.5$ (Emerenciano et al. 2017). To do this, one kilogram of hydrated lime was diluted in $450 \mathrm{~L}$ of water, allowed to settle for $2 \mathrm{~h}$ and then the supernatant $(150 \mathrm{~L})$ was added to the PB tank.

\section{Statistical analysis}

The data were assessed for normality and homoscedasticity using the Kolmogorov-Smirnov and Levene tests, respectively. The parameters of water and growth were $\log _{10}$ transformed, whereas survival, organosomatic indices and proximal composition of tilapia and biofloc were arcsine-transformed for analysis. Statistical analysis for parameters of water, organosomatic indices and proximal composition data was performed using a one-way ANOVA, whereas data of productive performance of tilapia were analyzed using two-way ANOVA with treatment and date as fixed factors. Tukey's multiple comparisons test was carried out to determine the differences between treatments. All analyzes were performed with a nominal significance of 5\% (Zar 2010) with the Statistica V. 7.0 program (Dell Statistica, Round Rock, TX, USA).

\section{Results}

The results of the analysis of the physicochemical parameters of water measured at the time of filling the tanks, at the end of the biofloc maturation period and during the grow-out period of tilapia are shown in Table 1.

During the grow-out period, the physicochemical parameters of water, except temperature, were within the acceptable range for the tilapia culture in both treatments; however, the RW water parameters such as $\mathrm{pH}$, TDS, $\mathrm{NO}_{2}-\mathrm{N}, \mathrm{NO}_{3}-\mathrm{N}$ and $\mathrm{KH}$ were significantly greater $(p<0.05)$, when compared to those recorded in the TB treatment. The variation of water parameters during the grow-out period of the Nile tilapia are shown in Fig. 2 (T, TDS and pH) and Fig. 3 (SS, OD and $\mathrm{NH}_{4}-\mathrm{N}$ ). The water lost by evaporation or biofloc extraction corresponded to $4.2 \%$ every 2 weeks, with a cumulative total of $29 \%$ which was equivalent to $1.06 \mathrm{~m}^{3}$ of water consumed per treatment after 14 weeks of culture.

The survival of tilapia in both treatments was $>98 \%$. After 14 weeks of culture, the final weight of tilapia in TB $(163.09 \pm 42.34 \mathrm{~g})$ and RW $(159.23 \pm 39.92 \mathrm{~g})$ was similar. The other productive performance variables such as DWG, SGR, K. FCR, CV, TP and fillet yield were similar between treatments (Table 2).

At the end of the study, proximal composition of tilapia and the gonadosomatic and hepatosomatic indices of both sexes of tilapia were similar among treatments. The protein and lipid contents of biofloc were similar between treatments; however, the ash content was significantly higher in the RW treatment (Table 2).

\section{Discussion}

The sustainability of the aquaculture sector depends on efficient management of resources, especially water (FAO 2018). In this study, reuse water contained a high concentration of TDS, but as the maturation period progressed, a reduction in TDS concentration was observed, which could be related to the proliferation of microalgae since this microorganism utilized inorganic nutrients for growth (Natrah et al. 2013). The proliferation of microalgae resulted in a photoautotrophic biofloc during the first weeks of culture; these microorganisms, in addition to oxygenating the water, were an important source of macro and micronutrients for the cultivated organisms (Gallardo-Collí et al. 2019). When establishing cultures with biofloc, it is necessary to fertilize the water to promote the proliferation of microorganisms (Pérez-Fuentes et al. 2016); therefore, a potential benefit derived from the use of water with a high concentration of nutrients, such as that derived from BFT culture effluents, is the reduction in the amount of inorganic fertilizers required to stimulate primary productivity since the effluents serve as an inoculum (Krummenauer et al. 2014). 


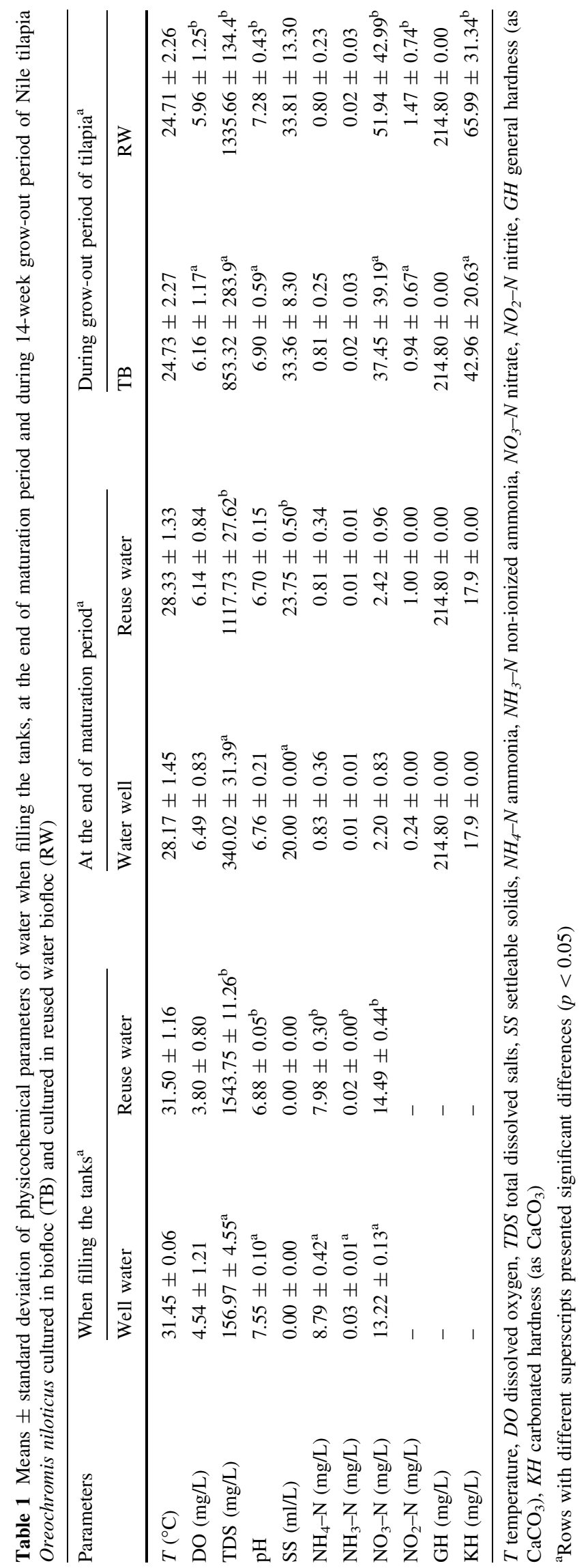



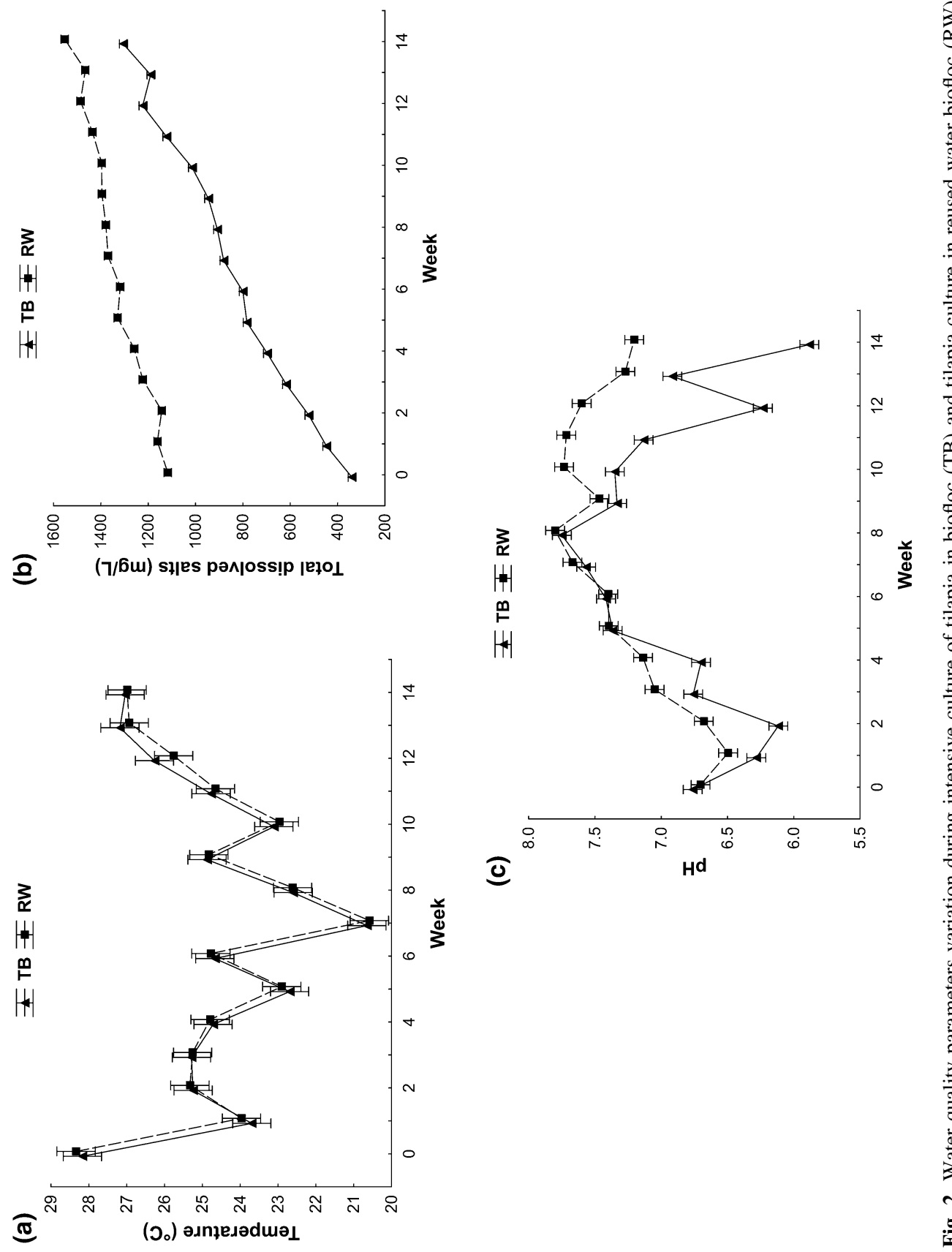


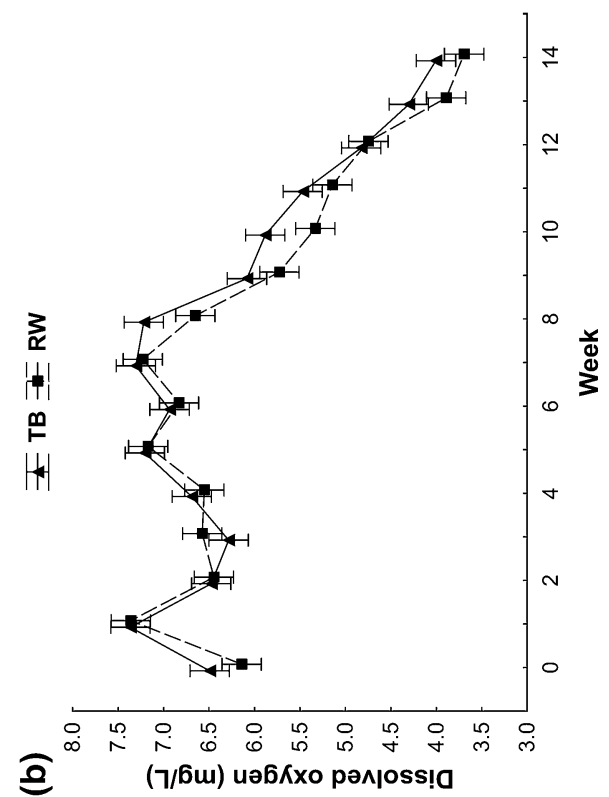

อ (7/6u) иәбКхо рәкןоss!a
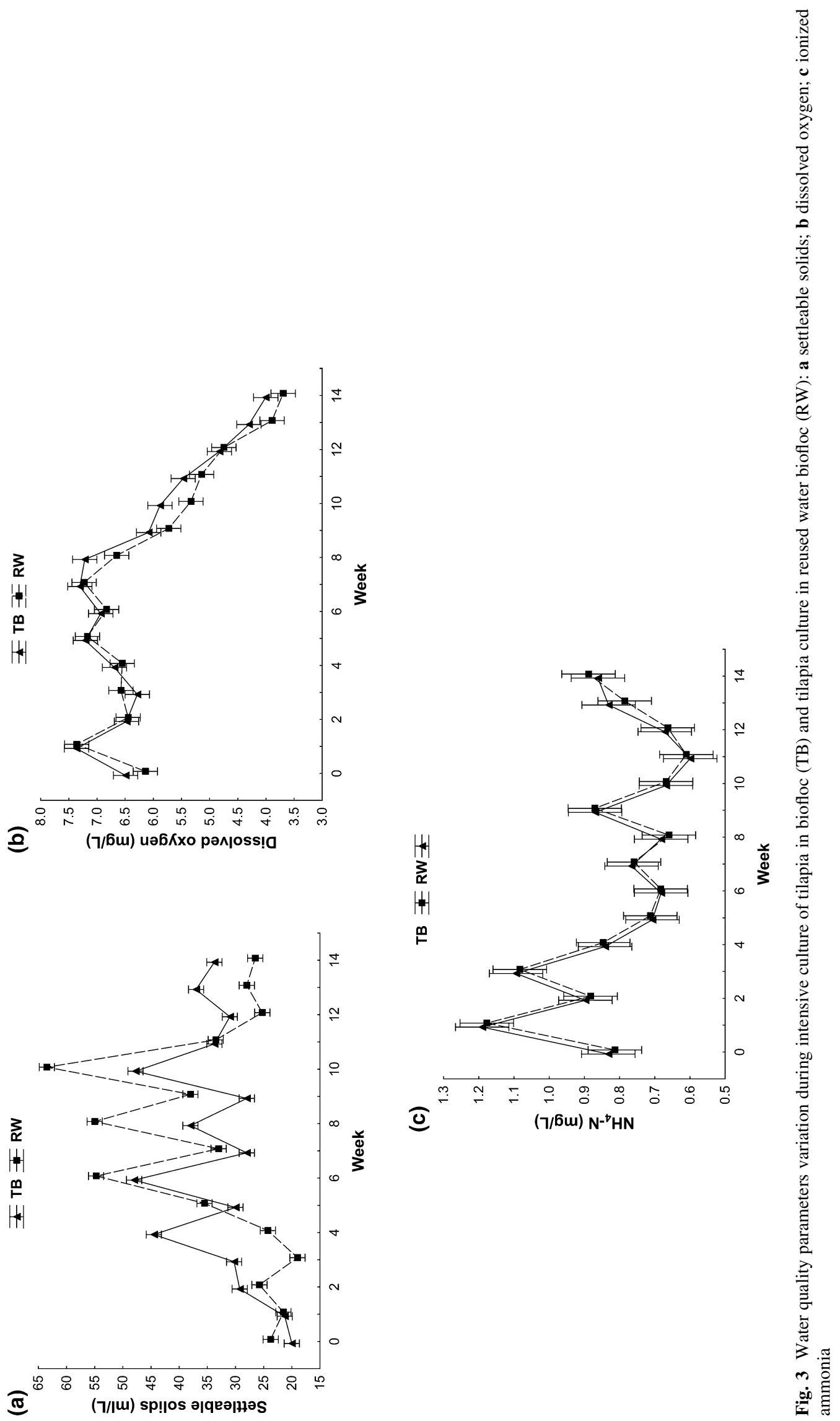

4. Springer 
Table 2 Productive performance, organosomatic indices, proximal composition of tilapia and proximal composition of biofloc after 14-week grow-out period of Nile tilapia Oreochromis niloticus cultured in biofloc (TB) and cultured in reused water biofloc $(\mathrm{RW})($ mean $\pm \mathrm{SD})$

\begin{tabular}{|c|c|c|}
\hline \multirow[t]{2}{*}{ Variables } & \multicolumn{2}{|l|}{ Treatment $^{\mathrm{a}}$} \\
\hline & TB & RW \\
\hline \multicolumn{3}{|l|}{ Performance } \\
\hline $\mathrm{S}(\%)$ & $100 \pm 0.00$ & $98.75 \pm 2.50$ \\
\hline IW $(g)$ & $79.83 \pm 12.83$ & $78.74 \pm 15.94$ \\
\hline FW (g) & $163.09 \pm 42.34$ & $159.23 \pm 38.92$ \\
\hline $\mathrm{K}$ & $3.99 \pm 0.34$ & $4.01 \pm 0.34$ \\
\hline SGR (\%/day) & $0.72 \pm 0.21$ & $0.70 \pm 0.24$ \\
\hline DGR (g/day) & $0.83 \pm 0.25$ & $0.79 \pm 0.28$ \\
\hline FCR & $2.22 \pm 0.72$ & $2.40 \pm 1.03$ \\
\hline CV $(\%)$ & $21.51 \pm 3.03$ & $22.31 \pm 3.25$ \\
\hline $\mathrm{TP}\left(\mathrm{kg} / \mathrm{m}^{3}\right)$ & $16.30 \pm 0.00$ & $15.63 \pm 0.40$ \\
\hline Fillet yield (\%) & $21.83 \pm 2.11$ & $22.39 \pm 2.95$ \\
\hline \multicolumn{3}{|c|}{ Organosomatic indices of male fish (\%) } \\
\hline Gonadosomatic index & $1.34 \pm 0.58$ & $1.57 \pm 0.50$ \\
\hline Hepatosomatic index & $2.64 \pm 1.17$ & $3.12 \pm 1.02$ \\
\hline \multicolumn{3}{|c|}{ Organosomatic indices of female fish $(\%)$} \\
\hline Gonadosomatic index & $5.01 \pm 1.93$ & $4.72 \pm 2.47$ \\
\hline Hepatosomatic index & $2.99 \pm 1.06$ & $2.69 \pm 0.99$ \\
\hline \multicolumn{3}{|c|}{ Proximal composition of tilapia $(\%)^{\mathrm{b}}$} \\
\hline Moisture & $77.31 \pm 0.87$ & $77.35 \pm 0.49$ \\
\hline Crude protein & $19.11 \pm 0.52$ & $19.08 \pm 0.72$ \\
\hline Total lipids & $2.24 \pm 0.61$ & $2.22 \pm 0.22$ \\
\hline Ash & $1.36 \pm 0.11$ & $1.34 \pm 0.07$ \\
\hline \multicolumn{3}{|c|}{ Proximal composition of biofloc $(\%)^{\mathrm{c}}$} \\
\hline Moisture & $86.88 \pm 4.81$ & $86.47 \pm 4.71$ \\
\hline Crude protein & $36.83 \pm 7.71$ & $35.90 \pm 8.10$ \\
\hline Total lipids & $4.14 \pm 2.90$ & $4.45 \pm 4.53$ \\
\hline Ash & $11.39 \pm 1.31^{\mathrm{a}}$ & $13.61 \pm 0.05^{\mathrm{b}}$ \\
\hline
\end{tabular}

$S$ survival, $I W$ initial weight, $F W$ final weight, $K$ condition factor, $S G R$ specific growth ratio, $D G R$ daily growth ratio, $F C R$ feed conversion ratio, $C V$ coefficient of variation, $T P$ total production

${ }^{\mathrm{a}}$ Rows with different superscripts present significant differences $(p<0.05)$

${ }^{\mathrm{b}}$ The determination of crude protein, total lipids and ash was performed on wet weight

${ }^{c}$ The determination of crude protein, total lipids and ash was performed on dry basis

The low KH of the water observed at the end of the maturation period was associated with the type of commercial fertilizer used, which contained a high percentage of ammonia (55.5\%), a nitrogenous compound that is preferentially consumed by microalgae and used for the synthesis of biomass, the assimilation of ammonia by microalgae leads to a decrease in the alkalinity of the water $\left(3.13 \mathrm{~g}\right.$ alkalinity as $\mathrm{CaCO}_{3} / \mathrm{g} \mathrm{NH}_{4}-$ N) (Ebeling et al. 2006). During the growth period, the alkalinity of the water in both systems was corrected by adding calcium hydroxide; this water parameter was more stable in the RW treatment, which could have improved the health of the tilapias (Emerenciano et al. 2017).

During week seven of tilapia culture, the water temperature decreased to $20{ }^{\circ} \mathrm{C}$, which was caused by the presence of cold fronts in the Gulf of Mexico. This temperature is not optimal for tilapia cultivation $\left(28-30^{\circ} \mathrm{C}\right)$ (Emerenciano et al. 2017); however, in this study, the tilapia culture was established in a greenhouse using BFT which meant that the water temperature was maintained at a value significantly greater than the water temperature of the artesian well. The positive effect of BFT on tilapia culture and the protection of the system in a greenhouse have been previously reported by Crab et al. (2009), who indicated that the 
water temperature increased by up to $5{ }^{\circ} \mathrm{C}$ compared to the water of the influent; furthermore, under these culture conditions, the tilapia achieved a high survival and a high condition factor at harvest, results that resemble those observed in the present study.

During the growth period, the slope of TDS accumulation was higher in the TB treatment than in the RW treatment. This difference may have been due to a greater abundance of microalgae in the RW system, resulting from the consumption of nutrients derived from the mineralization processes carried out by bacteria and protozoa present in BFT systems (Avnimelech 2009). Microalgae, bacteria, protozoa, metazoa and particulate organic material are part of the biofloc and confer a high nutritional quality (Gallardo-Collí et al. 2019); so, it is probable that their consumption by tilapia contributed to the observed improvements in productive performance.

A decrease in water $\mathrm{pH}$ was recorded after the eighth week of the tilapia culture. This $\mathrm{pH}$ reduction in the water was accentuated in the TB treatment, which suggests greater $\mathrm{pH}$ stability resulted from the use of reuse water in the RW treatment. This observation is congruent with previous studies indicating minimal $\mathrm{pH}$ variation in the water of BFT cultures (Avnimelech 2009). Emerenciano et al. (2017) indicated that values below 7.0 are considered normal in BFT systems, although they can affect nitrification processes. In the present study, the influence of $\mathrm{pH}$ variability on the productive performance of tilapia was discarded.

Midway through the culture period, the SS concentration in the water was observed to exceed the recommended maximum value for tilapia cultivation $(50 \mathrm{ml} / \mathrm{L}$ ) (Hargreaves 2013) which was related to the elevated amount of food that entered the water by the increase in fish biomass. The excessive SS concentration was a result of the nitrogenous waste derived from the consumption of feed by tilapia which is subsequently used by heterotrophic bacteria to produce microbial biomass, consequentially causing an increase the production of biofloc (Pérez-Fuentes et al. 2016). The excessive production of biofloc was controlled using a settling chamber; this action was necessary to prevent gill blockage by excess solids present in the water (Hargreaves 2013). The partial removal of biofloc from water improves biofiltration and decreases nitrate concentration; however, its extraction can affect the microbial community by removal of microorganisms associated with the biofloc (Ray et al. 2010).

Previous studies have suggested that in biofloc cultures, fish growth and the increase in microbial biomass reduce the concentration of dissolved oxygen in the water (Hargreaves 2013). This is coherent with the results of the present study whereby, following the seventh week of tilapia culture, the DO concentration in the water decreased in both treatments which was attributed to both the growth of the fish and the continuous increase in the concentration of SS. Another factor that affects the DO concentration in biofloc systems is the C:N ratio; for instance, values in the range of 15:1-20:1 cause a dramatic reduction in the DO concentration immediately after the carbon source enters the water (Pérez-Fuentes et al. 2016). In the present study, this effect was avoided by establishing a $\mathrm{C}: \mathrm{N}$ ratio of 12.5:1 and efficient water aeration.

The $\mathrm{NH}_{4}-\mathrm{N}$ and $\mathrm{NH}_{3}-\mathrm{N}$ concentrations were similar between treatments and were maintained at a concentration $<1 \mathrm{mg} / \mathrm{L}$ for most of the grow-out period, which can be attributed to both the $\mathrm{C}: \mathrm{N}$ ratio used during the study and the molasses application strategy, factors that kept the concentration of ionized and nonionized ammonia within the tolerable range for the tilapia culture (Pérez-Fuentes et al. 2016). Emerenciano et al. (2017) indicated that the addition of molasses can be prolonged until an increase in the total ammonia reaches a concentration $>1 \mathrm{mg} / \mathrm{L}$. Also, this strategy could reduce the production of biofloc since the limitation of the organic carbon source will decrease the heterotrophic bacterial biomass. The concentration of $\mathrm{NO}_{2}-\mathrm{N}$ and $\mathrm{NO}_{3}-\mathrm{N}$ in the water of the RW treatment were outside the "ideal range" for biofloc cultures as recommended by Emerenciano et al. (2017); however, it has been demonstrated that Nile Tilapia can tolerate concentrations of nitrite and nitrate above the values observed in this study without adversely affecting productive performance (Widanarni and Maryam 2012).

On the other hand, the water consumption in both treatments during the grow-out period was less than the value of $40 \%$ previously estimated by Verdegem and Bosma (2009), which confirms that the implementation of BFT cultures with reuse water can be used to further reduce the water consumption derived from freshwater aquaculture. In addition, when BFT cultures are developed using reuse water, the discharge of nutrients into natural water bodies decreases (Tucker et al. 2015).

The survival of juvenile tilapia cultivated with reuse water from BFT systems was high $(>98 \%)$. This result suggests that reuse water derived from previous BFT cultures can be used in the development of a new biofloc culture and does not negatively impact the survival of tilapia. The survival rate recorded in the present 
study is comparable to the rate of survival reported for tilapia (93-95\%) when cultivated in biofloc from first use water or reused water (50\% inclusion) (Widanarni and Maryam 2012; Pérez-Fuentes et al. 2016; Malpartida et al. 2017), and the high survival rate (99\%) observed in the shrimp L. vannamei cultivated in biofloc with reuse water at a $100 \%$ inclusion level (Krummenauer et al. 2014).

The DWG of the tilapia ( $0.79 \mathrm{~g} /$ day) observed in the RW treatment exhibited similar values to those reported for the mixed culture of tilapia $O$. niloticus with biofloc (0.52-0.83 g/day) (Widanarni and Maryam 2012), which suggests that the growth of tilapia during their culture in biofloc with reuse water was not affected by the quality of the water from the previous BFT culture; thus, the useful life of the water can be prolonged at least for the development of a new biofloc culture cycle. This is consistent with a previous report by Krummenauer et al. (2014) who indicated that the use of the same water from prior BFT cultures is highly beneficial for culture white shrimp L. vannamei, because good water quality is maintained, and the productive performance is increased.

The $\mathrm{K}$ of tilapia in both treatments was greater than 2, suggesting that fish maintained good health throughout the cultivation period, as well as adapting to the stress caused by a decrease in water temperature. A similar effect was observed by Crab et al. (2009) when an average condition factor of 2.2 was recorded for tilapia during cultivation in biofloc at low temperatures $\left(18^{\circ} \mathrm{C}\right)$. On the other hand, a decrease in the FCR (1.01-1.14) of male tilapia cultivated using BFT has previously been reported by Pérez-Fuentes et al. (2016), who indicated that the intake of biofloc contributes to the diet of the fish and reduces the consumption of feed. Additionally, other studies have indicated that biofloc consumed by fish improves digestion and decreases the feed conversion ratio (Avnimelech 2009). In our study, an FCR greater than 2 was expected due to the interaction between sexes, since the tilapia culture was of mixed sexes, energy from food may have been partially used to satisfy reproductive needs, such as gonad maturation or territorial defense (Orlando et al. 2017).

At the end of the study, in both treatments, the gonadosomatic index of the female tilapia was greater than the hepatosomatic index. This result may be due to increased deposition of proteins and/or lipids in this organ because during the vitellogenesis process, a large oocyte growth occurs due to the influx of plasma proteins and lipids, including vitellogenin synthesized in the liver (Oliveira et al. 2014). Previous studies indicate that Nile tilapia cultured in BFT systems improve their reproductive performance due to the contribution of nutrients from the biofloc (Ekasari et al. 2013). On the other hand, an increase in the CV of the fish was observed, 17.25-23.93\%, which indicates the presence of hierarchies and competition among fish (Jobling 1995), behavior that was accentuated, mainly between male tilapia, due to the establishment of a culture of tilapia with mixed sexes.

After 14 weeks of cultivation, the TP of tilapia $\left(16 \mathrm{~kg} / \mathrm{m}^{3}\right)$ was similar to the value reported in previous studies (16-18 kg/m³ ) (Pérez-Fuentes et al. 2016), which indicates that the cultivation of tilapia in biofloc with reuse water did not affect the productive performance. The fillet yield of fish $(22 \%)$ in both treatments was lower than the minimum value of $26 \%$ reported by Pérez-Fuentes et al. (2016) in tilapias of 230 g. However, this low value is justified by differences in weight, since there is a positive correlation between tilapia weight and fillet weight (Rutten et al. 2004). Additionally, the proximal composition of the tilapia was not affected, as indicated by the protein, lipid and ash percentages which are similar to the values reported in heavier tilapia (530 g) with a fillet yield of 30\% (Michelato et al. 2016).

\section{Conclusion}

The reuse water from BFT systems used to establish new biofloc cultures prolongs the useful life of the water and reduces overall water consumption. The cultivation of Nile tilapia in biofloc can be established with reuse water from BFT systems without adverse effects on their survival, productive performance, proximal composition and gonadal maturity. Additionally, good water quality can be maintained during cultivation; therefore, it could be considered as an additional strategy to maintain or increase production of Nile tilapia.

Acknowledgements The authors would also like to thank two anonymous reviewers for their valuable comments on an earlier version of this manuscript. A.G.C. is a recipient of a doctoral fellowship by the National Council for Science and Technology (CONACyT) Mexico (Grant 229713). 


\section{Compliance with ethical standards}

Conflict of interest The authors have no conflict of interest to declare.

Open Access This article is distributed under the terms of the Creative Commons Attribution 4.0 International License (http:// creativecommons.org/licenses/by/4.0/), which permits unrestricted use, distribution, and reproduction in any medium, provided you give appropriate credit to the original author(s) and the source, provide a link to the Creative Commons license, and indicate if changes were made.

\section{References}

AOAC (1990) Official methods of analysis of the association of official analytical chemists, 15th edn. Association of Official Analytical Chemists, Arlington

Avnimelech Y (2009) Biofloc technology - a practical guide book. The World Aquaculture Society, Baton Rouge

Boyd CE (2003) Guidelines for aquaculture effluent management at the farm-level. Aquaculture 226:101-112. https://doi.org/10. 1016/S0044-8486(03)00471-X

Crab R, Kochva M, Verstraete W, Avnimelech Y (2009) Bio-flocs technology application in over-wintering of tilapia. Aquacult Eng 40:105-112. https://doi.org/10.1016/j.aquaeng.2008.12.004

Day SB, Salie K, Stander HB (2016) A growth comparison among three commercial tilapia species in a biofloc system. Aquacult Int 24:1309-1322. https://doi.org/10.1007/s10499-016-9986-Z

Dekić R, Savić N, Manojlović M, Golub D, Pavličević J (2016) Condition factor and organosomatic indices of rainbow trout (Onchorhynchus mykiss, Wal.) from different brood stock. Biotech Anim Husband 32:229-237. https://doi.org/10.2298/ BAH1602229D

Ebeling JM, Timmons MB, Bisogni JJ (2006) Engineering analysis of the stoichiometry of photoautotrophic, autotrophic, and heterotrophic removal of ammonia-nitrogen in aquaculture systems. Aquaculture 257:346-358. https://doi.org/10.1016/j. aquaculture.2006.03.019

Ekasari J, Zairin M Jr, Putri DU, Sari NP, Surawidjaja EH, Bossier P (2013) Biofloc-based reproductive performance of Nile tilapia Oreochromis niloticus L. broodstock. Aquacult Res 46:509-512. https://doi.org/10.1111/are.12185

Emerenciano MGC, Martínez-Córdova LR, Martínez-Porchas M, Miranda-Baeza A (2017) Biofloc technology (BFT): a tool for water quality management in aquaculture. In: Hlanganani T (ed) water quality. InTech, Rijeka, pp 91-109. https://doi.org/10. $5772 / 6641$

FAO (2018) The State of World Fisheries and Aquaculture. Meeting the sustainable development goals. Food and Agriculture Organization, Rome

Gallardo-Collí A, Pérez-Rostro CI, Hernández-Vergara MP, Pérez-Legaspi IA (2019) Microeukaryote community and the nutritional composition of the biofloc during Nile tilapia culture in water-reusing biofloc systems. Aquacult Int 4:4. https:// doi.org/10.1007/s10499-018-0335-2

Hargreaves JA (2013) Biofloc production systems for aquaculture. Southern Regional Aquaculture Center publication 4503

Jobling M (1995) Simple indices for the assessment of the influences of social environment on growth performance, exemplified by studies on Arctic charr. Aquacult Int 3:60-65. https://doi.org/10.1007/BF00240922

Krummenauer D, Samocha T, Poersch L, Lara G, Wasielesky W Jr (2014) The reuse of water on the culture of pacific white shrimp Litopenaeus vannamei, in BFT system. J World Aquac Soc 45:3-14. https://doi.org/10.1111/jwas.12093

Liu W, Luo G, Tan H, Sun D (2016) Effects of sludge retention time on water quality and bioflocs yield, nutritional composition, apparent digestibility coefficients treating recirculating aquaculture system effluent in sequencing batch reactor. Aquacult Eng 72:58-64. https://doi.org/10.1016/j.aquaeng.2016.04.002

Malpartida PJJ, Carvalho FJW, De Espirito SCM, Vinatea L (2017) Production of Nile tilapia Oreochromis niloticus grown in BFT using two aeration systems. Aquacult Res 49:222-231. https://doi.org/10.1111/are.13451

Michelato M, De Oliveira VLV, Xavier TO, De Moura LB, De Almeida FLA, Pedrosa VB, Furuya VRB, Furuya WM (2016) Dietary lysine requirement to enhance muscle development and fillet yield of finishing Nile tilapia. Aquaculture 457:124-130. https://doi.org/10.1016/j.aquaculture.2016.02.022

Natrah FMI, Bossier P, Sorgeloos P, Yusoff FM, Defoirdt T (2013) Significance of microalgal-bacterial interactions for aquaculture. Rev Aquacult 6:48-61. https://doi.org/10.1111/raq.12024

Oliveira MM, Ribeiro T, Orlando TM, Oliveira DGS, Drumond MM, Freitas RTF, Rosa PV (2014) Effects crude protein levels on female Nile tilapia (Oreochromis niloticus) reproductive performance parameters. Anim Reprod Sci 150:62-69. https://doi. org/10.1016/j.anireprosci.2014.08.006

Orlando TM, Oliveira MM, Paulino RR, Costa AC, Allaman IB, Rosa PV (2017) Reproductive performance of female Nile tilapia (Oreochromis niloticus) fed diets with different digestible energy levels. R Bras Zootec 46:1-7. https://doi.org/10.1590/ S1806-92902017000100001

Pérez-Fuentes JA, Pérez-Rostro CI, Hernández-Vergara MP (2013) Pond-reared Malaysian prawn Macrobrachium rosenbergii with the biofloc system. Aquaculture 400-401:105-110. https://doi.org/10.1016/j.aquaculture.2013.02.028

Pérez-Fuentes JA, Hernández-Vergara MP, Pérez-Rostro CI, Fogel I (2016) C: N ratios affect nitrogen removal and production of Nile tilapia Oreochromis niloticus raised in a biofloc system under high density cultivation. Aquaculture 425:247-251. https://doi.org/10.1016/j.aquaculture.2015.11.010 
Pérez-Fuentes JA, Pérez-Rostro CI, Hernández-Vergara MP, Monroy-Dosta MDC (2018) Variation of the bacterial composition of biofloc and the intestine of Nile tilapia Oreochromis niloticus, cultivated using biofloc technology, supplied different feed rations. Aquacult Res 49:3658-3668. https://doi.org/10.1111/are.13834

Ray AJ, Lewis BL, Browdy CL, Leffler JW (2010) Suspended solids removal to improve shrimp (Litopenaeus vannamei) production and an evaluation of a plant-based feed in minimal-exchange, superintensive culture systems. Aquaculture 299:89-98. https://doi.org/10.1016/j.aquaculture.2009.11.021

Rutten MJM, Bovenhuis H, Komen H (2004) Modeling fillet traits based on body measurements in three Nile tilapia strains (Oreochromis niloticus L.). Aquaculture 231:113-122. https://doi.org/10.1016/j.aquaculture.2003.11.002

Tucker CS, Pote JW, Wax CL, Brown TW (2015) Improving water-use efficiency for Ictalurid catfish pond aquaculture in Northwest Mississippi, USA. Aquacult Res 48:447-458. https://doi.org/10.1111/are.12893

Verdegem MCJ, Bosma RH (2009) Water withdrawal for brackish and inland aquaculture, and options to produce more fish in ponds with present water use. Water Policy 11:52-68. https://doi.org/10.2166/wp.2009.003

Widanarni Ekasari J, Maryam S (2012) Evaluation of biofloc technology application on water quality and production performance of red tilapia Oreochromis sp. cultured at different stocking densities. Hayati J Biosci 19:73-80. https://doi.org/10.4308/hjb. 19.2.73

Zar JH (2010) Biostatistical analysis, 5th edn. Prentice Hall, Upper Saddle River

\section{Publisher's Note}

Springer Nature remains neutral with regard to jurisdictional claims in published maps and institutional affiliations. 